\title{
Tautomerism in Quinoxalines Derived from the 1,4-Naphthoquinone Nucleus: Acid Mediated Synthesis, X-ray Molecular Structure of 5-Chlorobenzo[f]quinoxalin-6-ol and Density Functional Theory Calculations
}

\author{
Javier A. G. Gomez, Mateus R. Lage, José Walkimar de M. Carneiro,* \\ Jackson A. L. C. Resende and Maria D. Vargas* \\ Instituto de Química, Universidade Federal Fluminense, \\ Campus do Valonguinho, Centro, 24020-141 Niterói-RJ, Brazil
}

\begin{abstract}
A reação de tert-butil 2-(3-cloro-1,4-dioxo-1,4-di-hidronaftalen-2-ilamino)etilcarbamato com $\mathrm{CF}_{3} \mathrm{COOH} / \mathrm{CH}_{2} \mathrm{Cl}_{2}$ fornece 5-cloro-3,4-di-hidrobenzo[f]quinoxalin-6(2H)-ona. Este composto sofre desidrogenação promovida por ácido na presença de água para dar a 5-clorobenzo[f]quinoxalin-6-ol, inédita. A estrutura molecular no estado sólido, determinada por um estudo de difração de raios X (XRD), e os dados em solução confirmam que a benzoquinoxalina existe na forma do tautômero enol-imina, tanto no estado sólido, quanto em solução, diferentemente de 5-cloro-3,4-di-hidrobenzo[f]quinoxalin-6(2H)-ona que exibe o arranjo ceto-amino. Cálculos de teoria do funcional da densidade (DFT) confirmam a preferência da benzoquinoxalina e dos compostos análogos contendo grupos $\mathrm{H}$ ou $\mathrm{CH}_{3}$ no lugar do $\mathrm{Cl}$ pela forma enol-imina. Sugere-se que a preferência da benzoquinoxalina pela estrutura enol-imina se deva ao maior caráter aromático desta estrutura em comparação com a forma ceto-amina. Os cálculos DFT dos dois tautômeros das benzo[ $a]$ fenazin-5(7H)-onas análogas às benzo[f]quinoxalin-6(4H)-onas indicaram que as estabilidades relativas são dominadas por efeitos de solvatação, no primeiro caso, e pelo grau de aromaticidade no segundo.
\end{abstract}

The reaction of tert-butyl 2-(3-chloro-1,4-dioxo-1,4-dihydronaphthalen-2-ylamino) ethylcarbamate with $\mathrm{CF}_{3} \mathrm{COOH} / \mathrm{CH}_{2} \mathrm{Cl}_{2}$ yields 5-chloro-3,4-dihydrobenzo[f]quinoxalin$6(2 \mathrm{H})$-one which undergoes acid-promoted dehydrogenation in the presence of water to give novel 5-chlorobenzo[f]quinoxalin-6-ol. The molecular structure of 5-chlorobenzo[f]quinoxalin6-ol in the solid state, determined by an X-ray diffraction (XRD) study, and the solution data confirm that it exists as the enol-imine tautomer, both in the solid state and in solution, differently from 5-chloro-3,4-dihydrobenzo[f]quinoxalin-6(2H)-one, which exhibits the keto-amine arrangement. Density functional theory (DFT) calculations confirmed the preference of 5-chlorobenzo[f]quinoxalin-6-ol and of the derivatives containing $\mathrm{H}$ and $\mathrm{CH}_{3}$ groups in place of the $\mathrm{Cl}$ atom for the enol-imine tautomer. It is suggested that the enol-imine structure is preferred for 5-chlorobenzo[f]quinoxalin-6-ol as a consequence of the higher aromatic character of this structure in comparison with the keto-amine form. DFT calculations carried out on the two tautomers of the benzo $[a]$ phenazin- $5(7 \mathrm{H})$-ones analogous to the benzo[f]quinoxalin- $6(4 \mathrm{H})$-ones showed that the relative stabilities are dominated by solvation effects in the first case and the degree of aromaticity, in the latter.

Keywords: quinoxalines, 1,4-naphthoquinones, tautomerism, X-ray structure, DFT calculations

\section{Introduction}

Quinoxalin derivatives have been the subject of intensive industrial and academic investigation due to their importance as intermediates for the synthesis of pharmaceuticals and new materials. This nucleus is a

*e-mail: mdvargas@vm.uff.br, walk@vm.uff.br privileged molecular scaffold, present in a large number of molecules with a wide spectrum of biological activities, ${ }^{1}$ e.g., trypanocidal,,$^{2,3}$ antimalarial, ${ }^{4,5}$ antitubercular, ${ }^{6,7}$ antimicrobial, ${ }^{8}$ antitumoral, ${ }^{9}$ anti-proliferative, ${ }^{10,11}$ antithrombotic, ${ }^{12}$ anti-HIV, ${ }^{13}$ among others. Quinoxalines have been investigated as luminescent materials, ${ }^{14,15}$ fluorescent probes ${ }^{16}$ and as constituents of donor-acceptor type polymers for optoelectronics. ${ }^{17}$ Their chelating 
ability has been used for the preparation of molecular sensors ${ }^{18,19}$ and hybrid coordination polymers. ${ }^{20}$

Of interest to this paper are the quinoxalines derived from the 1,4-naphthoquinone nucleus which include the benzophenazines reported by Silva Junior et al. (Figure 1a, $\mathbf{a}^{21}$ and the dihydrobenzoquinoxalines (Figure 1b), studied extensively by Kallmayer and Seyfang. ${ }^{25-34}$ The benzophenazines shown in Figure 1a have been obtained from the reactions of phenylenediamine with 2-hydroxy-3-R-1,4-naphthoquinones in $\mathrm{AcOH}$, under heating, in the presence (a-f) ${ }^{21,22}$ or absence of $\mathrm{AcONa}(\mathbf{g}) .{ }^{23}$ Unusual dimeric phenazines $\mathbf{h}$ have been synthesized in high yields by reacting lapachol (2-hydroxy3-(3-methyl-2-butenyl)-1,4-naphthoquinone) with neat alkylamines. ${ }^{24}$ The reactions of ethylene diamines or 1,2-cyclohexyldiamine ${ }^{34}$ with 1,4-naphthoquinone $(\mathrm{R}=\mathrm{H}), 2,3$-dibromo or dichloro-1,4-naphthoquinone ( $\mathrm{R}=\mathrm{Cl}$ or $\mathrm{Br}$ ), 2,3-phthalimido-1,4-naphthoquinone $\left(\mathrm{R}=\mathrm{NHAc}, \mathrm{NH}_{2}\right)^{29}$ and 2-alkyl or 2-aryl,3-halogen1,4-naphthoquinones, in $\mathrm{CH}_{2} \mathrm{Cl}_{2} /$ ethanol, ${ }^{26}$ have yielded the dihydrobenzoquinoxalines shown in Figure $1 \mathrm{~b}$.

Following our continuing interest in aminonaphthoquinones $^{35-38}$ and their metal complexes ${ }^{39-41}$ as potential antimicrobial and anticancer agents, our group has investigated the possibility of synthesizing molecular hybrids from 2,3-dichloro-1,4-naphthoquinone and $N$-Boc-monoprotected diamines $\left(\mathrm{NH}_{2}\left(\mathrm{CH}_{2}\right)_{\mathrm{n}} \mathrm{NHBoc}\right)$, whose deprotection would be followed by further extension of the diamine chain with nitrogen or oxygen containing fragments for coordination with metal ions. This tactic has proven successful for the diamines with a linear carbon chain longer than $n=3,{ }^{42}$ and the results will be reported elsewhere. Under the conditions employed for the deprotection of the $\mathrm{NH}_{2}\left(\mathrm{CH}_{2}\right)_{2} \mathrm{NHBoc}$ derivative $\mathbf{1}$, however, 5-chloro-3,4-dihydrobenzo[f]quinoxalin-6(2H)-one $\mathbf{2}^{26}$ was obtained instead, together with the dehydrogenated compound 5-chlorobenzo[f]quinoxalin-6-ol 3 (Figure 2). 5-R-3,4-Dihydrobenzo[f]quinoxalin-6(2H)-ones $\left(\mathrm{R}=\mathrm{CH}_{3}\right.$, $\mathrm{OCH}_{3}, \mathrm{CN}$ and NHAc, Figure 1b) were reported previously to undergo base and acid promoted oxidation to the respective benzoquinoxalin-6-ol derivatives analogous to 3 , in good yields and trace amounts, respectively. ${ }^{43}$ The benzophenazines and dihydrobenzoquinoxalines illustrated in Figure 1 in their keto-amine form could, in principle, exist as the enol-imine tautomer observed for $\mathbf{3}$ (Figure 2) and analogous benzoquinoxalines. ${ }^{44}$

Herein we describe a novel route to the acid mediated oxidation of $\mathbf{2}$ and the solution and solid state characterization of 5-chlorobenzo[f] quinoxalin-6-ol 3, including an X -ray diffraction (XRD) analysis. We also report the results of density functional theory (DFT) calculations to determine the relative stabilities of the two tautomers of quinoxalines related to $\mathbf{2}$ and $\mathbf{3}$ containing different substituents in place of $\mathbf{C l}$, and of benzophenazines $\mathbf{b}, \mathbf{d}$ and $\mathbf{g}$ (Figure 1a).

\section{Experimental}

\section{General methods}

2,3-dichloro-1,4-naphthoquinone (Aldrich), 1,2-ethanodiamine (Aldrich), di-tert-butyl-dicarbonate (Aldrich), trifluoroacetic acid (Aldrich), $\mathrm{MeCN}$, EtOAc, hexane, EtOH (Vetec), $\mathrm{CH}_{2} \mathrm{Cl}_{2}, \mathrm{Na}_{2} \mathrm{SO}_{4}$ and $\mathrm{NaHCO}_{3}$ (Vetec) were used as received. tert-Butyl $N$-(2-aminoethyl)carbamate

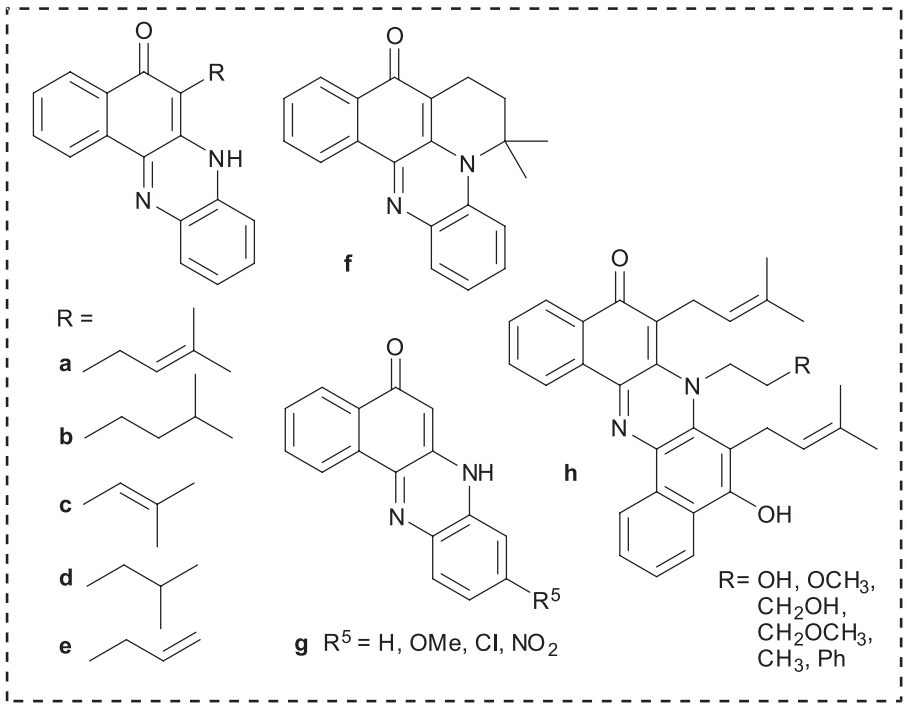

(a)

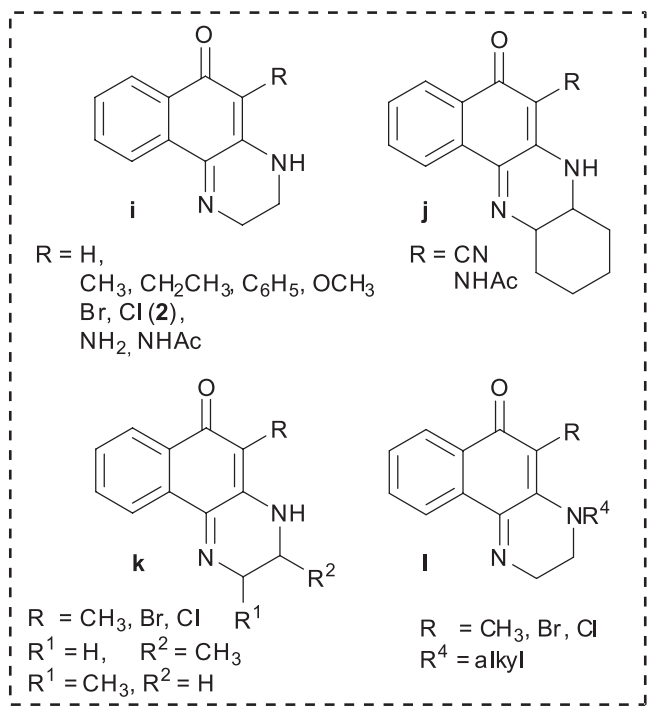

(b)

Figure 1. Benzophenazines (a) and dihydrobenzoquinoxalines (b) synthesized from 1,4-naphthoquinones. 

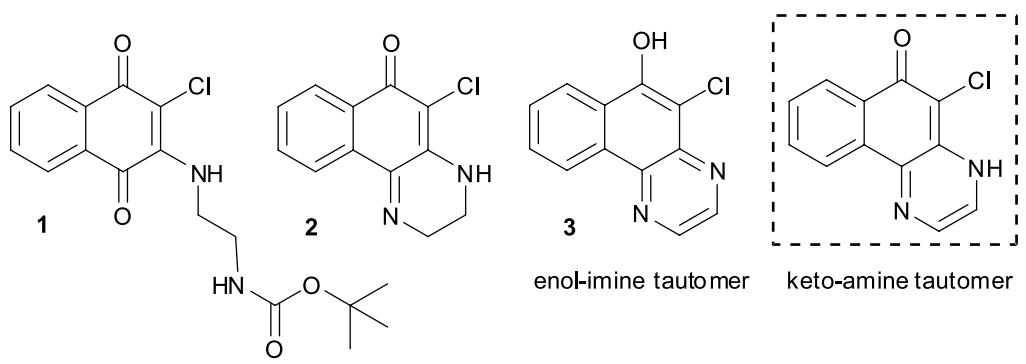

Figure 2. Structures of the compounds synthesized in this study and of the possible tautomers of compound 3 .

was prepared as described in the literature for tert-butyl $N$-(3-aminopropyl)carbamate. ${ }^{45}$ All solvents were removed under reduced pressure. The reactions were monitored by thin layer chromatography (TLC) analysis on silicagel 60 $\mathrm{F}_{254}$ TLC plates with detection by UV absorption ( $254 \mathrm{~nm}$ ). Column chromatography (CC) was performed using Acros Organics silica gel $(35-70 \mu \mathrm{m})$ as the stationary phase and the solvent systems indicated in each experiment. Melting points (mp) were obtained on a ThermoFisher Scientific Digital Melting Point IA9100 apparatus. Infrared spectra were recorded as thin films using a Varian 660 FTIR spectrometer equipped with an attenuated total reflectance (ATR) sampling accessory, and the spectral data are reported in wavenumbers $\left(\mathrm{cm}^{-1}\right)$. Nuclear magnetic resonance (NMR) spectra were acquired in $\mathrm{CDCl}_{3}$, DMSO- $d_{6}$ or $\mathrm{CD}_{3} \mathrm{OD}$ as indicated using a Varian VNMRS $300 \mathrm{MHz}$ or Varian VNMRS $500 \mathrm{MHz}$ spectrometer, where ${ }^{1} \mathrm{H}$ and ${ }^{13} \mathrm{C}$ were measured at 500/300 and $125 \mathrm{MHz}$, respectively. ${ }^{1} \mathrm{H}$ NMR spectra are referenced to the $\mathrm{CDCl}_{3}(\delta 7.26 \mathrm{ppm})$, DMSO- $d_{6}(\delta 2.50$ $\mathrm{ppm})$ and $\mathrm{CD}_{3} \mathrm{OD}(\delta 3.31 \mathrm{ppm})$ residual solvent peaks. The hydrogen signals were attributed through coupling constant values and ${ }^{1} \mathrm{H} \times{ }^{1} \mathrm{H}$ COSY (correlation spectroscopy) experiments. ${ }^{13} \mathrm{C}$ NMR spectra were proton decoupled and referenced to $\mathrm{CDCl}_{3}(\delta 77.0 \mathrm{ppm})$ and DMSO- $d_{6}(\delta 39.4$ $\mathrm{ppm}$ ) residual solvents peaks.

Synthesis of tert-butyl 2-(3-chloro-1,4-dioxo-1,4-dihydronaphthalen-2-ylamino)ethylcarbamate (1)

Compound 1 was prepared from 2,3-dichloro1,4-naphthoquinone and tert-butyl $N$-(2-aminoethyl) carbamate according to literature procedures ${ }^{42,46}$ to give a red solid, 70\%, mp $131{ }^{\circ} \mathrm{C}$; anal. calcd. for $\mathrm{C}_{17} \mathrm{H}_{19} \mathrm{~N}_{2} \mathrm{O}_{4} \mathrm{Cl}$ : C, 58.21; H, 5.46; N, 7.99; found: C, 58.15; H, 5.70; N, 7.97\%; ${ }^{1} \mathrm{H}$ NMR (500 MHz, $\left.\mathrm{CDCl}_{3}\right) \delta 1.44$ (s, 9H, H13), 3.45 (br q, 2H, J $5.0 \mathrm{~Hz}, \mathrm{H} 12$ ), 3.97 (br q, 2H, J $5.0 \mathrm{~Hz}$, H11), 4.86 (br, 1H, NH), 6.50 (br, 1H, NH), $7.61(\mathrm{td}, 1 \mathrm{H}$, $J$ 1.3, 7.6 Hz, H6/H7), 7.71 (td, 1H, J 1.3, 7.6 Hz, H6/H7), 8.01 (dd, 1H, $J$ 0.9, $7.7 \mathrm{~Hz}, \mathrm{H} 5 / \mathrm{H} 8$ ), 8.13 (dd, 1H, $J$ 0.9, $7.7 \mathrm{~Hz}, \mathrm{H} 5 / \mathrm{H} 8$ ); IR (thin film) $\mathrm{v} / \mathrm{cm}^{-1} 3373$ (N-H, amide), $3338(\mathrm{~N}-\mathrm{H}$, amine), $1669(\mathrm{C}=\mathrm{O})$ and $1648(\mathrm{C}=\mathrm{O})$.
Synthesis of 5-chloro-3,4-dihydrobenzo[f $f$ quinoxalin$6(2 \mathrm{H})$-one $(2)^{26}$

To a stirred solution of tert-butyl 2-(3-chloro-1,4-dioxo1,4-dihydronaphthalen-2-ylamino)ethylcarbamate (1, $0.70 \mathrm{~g}, 2.0 \mathrm{mmol}$ ) in $5 \mathrm{~mL}$ of $\mathrm{CH}_{2} \mathrm{Cl}_{2}$ cooled in an ice bath, was added trifluoroacetic acid $(0.77 \mathrm{~mL}, 1.14 \mathrm{~g}$, $10.0 \mathrm{mmol}$ ), and the resulting wine red solution was stirred at room temperature in a closed system for $24 \mathrm{~h}$. After evaporation to dryness a saturated $\mathrm{Na}_{2} \mathrm{CO}_{3}$ solution was added and the mixture was washed with EtOAc $(40 \mathrm{~mL})$. The organic layer was separated and the aqueous layer was extracted with EtOAc $(3 \times 40 \mathrm{~mL})$. The combined organic extracts were dried (anhydrous $\mathrm{Na}_{2} \mathrm{SO}_{4}$ ) and the solvent, evaporated. The residue was purified by $\mathrm{CC}$ (hexane/EtOAc, 10/1 to 2/1, v/v) to give an orange solid, $0.40 \mathrm{~g}, 86 \%$, ; anal. calcd. for $\mathrm{C}_{12} \mathrm{H}_{9} \mathrm{~N}_{2} \mathrm{OCl} .0 .25 \mathrm{C}_{4} \mathrm{H}_{8} \mathrm{O}_{2}$ : $\mathrm{C}, 61.31 ; \mathrm{H}, 4.35 ; \mathrm{N}, 11.00$; found: $\mathrm{C}, 61.79 ; \mathrm{H}, 4.42$; $\mathrm{N}, 11.02 \%$, mp $128{ }^{\circ} \mathrm{C}$ (lit. $135-138{ }^{\circ} \mathrm{C}, \mathrm{C}_{12} \mathrm{H}_{9} \mathrm{~N}_{2} \mathrm{OCl}$ ); ${ }^{26}$ ${ }^{1} \mathrm{H}$ NMR $\left(500 \mathrm{MHz}, \mathrm{CDCl}_{3}\right) \delta 3.50(\mathrm{td}, 2 \mathrm{H}, J 2.6,6.5 \mathrm{~Hz}$, H11), 4.19 (t, 2H, J 6.5 Hz, H12), 7.57 (m, 2H, H5 e H8), 8.15 (m, 1H, H6/H7), 8.18 (m, 1H, H6/H7); ${ }^{13} \mathrm{C}$ NMR $\left(125 \mathrm{MHz}, \mathrm{CDCl}_{3}\right) \delta 37.2,48.4,109.0,123.8,126.1$, 131.1, 131.2, 139.5, 152.2, 176.3; IR (thin film) $\mathrm{v} / \mathrm{cm}^{-1}$ $3324(\mathrm{~N}-\mathrm{H}), 1737(\mathrm{C}=\mathrm{O}), 1575(\mathrm{C}=\mathrm{C})$. Solubility: DMSO, acetone, methanol, ethanol, $\mathrm{CH}_{2} \mathrm{Cl}_{2}, \mathrm{CHCl}_{3}$ and hexane; partially soluble in water and EtOAc.

\section{Synthesis of 5-chlorobenzo[f]quinoxalin-6-ol (3)}

Prepared from tert-butyl 2-(3-chloro-1,4-dioxo1,4-dihydronaphthalen-2-ylamino)-ethylcarbamate (1, $1.50 \mathrm{~g}, 4.3 \mathrm{mmol})$ in $10 \mathrm{~mL}$ of $\mathrm{CHCl}_{2}$ and trifluoroacetic acid $(1.64 \mathrm{~mL}, 2.43 \mathrm{~g}, 21.5 \mathrm{mmol})$ according to the procedure described above. Evaporation to dryness was followed by addition of EtOAc $(2 \times 20 \mathrm{~mL})$ and the insoluble residue discarded. The solution was then washed with water $(50 \mathrm{~mL})$, the organic layer was separated and the aqueous layer was extracted with EtOAc $(4 \times 40 \mathrm{~mL})$. The combined organic extracts were dried (anhydrous $\mathrm{Na}_{2} \mathrm{SO}_{4}$ ) and the solvent evaporated. The residue was 
purified by CC (hexane/EtOAc from 10:1 to 2:1) to give a pale yellow solid, $0.49 \mathrm{~g}, 46 \%, \mathrm{mp} 216^{\circ} \mathrm{C}$; anal. calcd. for $\mathrm{C}_{12} \mathrm{H}_{7} \mathrm{~N}_{2} \mathrm{OCl} .0 .25 \mathrm{H}_{2} \mathrm{O}: \mathrm{C}, 61.31 ; \mathrm{H}, 4.35 ; \mathrm{N}, 11.00$; found: $\mathrm{C}, 61.79 ; \mathrm{H}, 4.42 ; \mathrm{N}, 11.02 \% ;{ }^{1} \mathrm{H} \mathrm{NMR}\left(300 \mathrm{MHz}, \mathrm{CDCl}_{3}\right)$ $\delta 7.82$ (m, 2H, H11-H12), 8.37 (m, 1H, H6-H7), 8.83 (d, $1 \mathrm{H}, J 2.1 \mathrm{~Hz}, \mathrm{H} 5-\mathrm{H} 8), 8.93$ (d, 1H, J 2.1 Hz, H5-H8), 9.18 (m, 1H, H6-H7); ${ }^{13} \mathrm{C}$ NMR (125 MHz, $\left.\mathrm{CDCl}_{3}\right) \delta 109.7$, $122.5,127.1,128.3,129.2,129.3,137.1,139.9,141.1$, 144.7, 151.0; IR (thin film) $\mathrm{v} / \mathrm{cm}^{-1} 3199(\mathrm{O}-\mathrm{H}), 1596(\mathrm{C}=\mathrm{C})$. Solubility: DMSO, acetone, methanol, EtOAc, hexane and $\mathrm{CH}_{2} \mathrm{Cl}_{2}$, partially soluble in $\mathrm{H}_{2} \mathrm{O}$ and $\mathrm{CHCl}_{3}$.

Crystallography: molecular and crystal structure of 5-chlorobenzo[f]quinoxalin-6-ol (3)

XRD data were collected at $150 \mathrm{~K}$ on an Agilent Xcalibur Atlas Gemini Ultra diffractometer with Mo K $\alpha$ radiation (see Table 1). Data processing (including integration, scaling and absorption correction) was performed using CrysAlisPro software. ${ }^{47}$ The structure was solved using SHELXS-97 and

Table 1. Structural data and refinement parameters for $\mathbf{3}$

\begin{tabular}{|c|c|}
\hline Chemical formula & $\mathrm{C}_{12} \mathrm{H}_{7} \mathrm{ClN}_{2} \mathrm{O} .3 \mathrm{H}_{2} \mathrm{O}$ \\
\hline$M_{\mathrm{r}}$ & 284.69 \\
\hline Crystal system, space group & Monoclinic, $P 2_{1} / n$ \\
\hline Temperature / K & 150 \\
\hline$a, b, c / \AA$ & $13.2632(8), 6.6446(5), 14.0610(9)$ \\
\hline$\beta /$ degree & $95.131(6)$ \\
\hline$V / \AA^{3}$ & $1234.21(14)$ \\
\hline$Z$ & 4 \\
\hline Radiation type & Mo $K \alpha$ \\
\hline$\mu / \mathrm{mm}^{-1}$ & 0.32 \\
\hline Crystal size /mm & $0.47 \times 0.15 \times 0.12$ \\
\hline Habit/colour & Plate/yellow \\
\hline Absorption correction & Multi-scan \\
\hline$T_{\min }, T_{\max }$ & $0.888,1$ \\
\hline $\begin{array}{l}\text { No. of measured, independent and } \\
\text { observed }[I>2 \sigma(I)] \text { reflections }\end{array}$ & $7362,2175,1538$ \\
\hline$R_{\text {int }}$ & 0.049 \\
\hline$R\left[F^{2}>2 \sigma\left(F^{2}\right)\right], w R\left(F^{2}\right), S$ & $0.053,0.149,1.13$ \\
\hline No. of reflections & 2175 \\
\hline No. of parameters & 192 \\
\hline No. of restraints & 9 \\
\hline $\mathrm{H}$-atom treatment & $\begin{array}{l}\mathrm{H} \text { atoms treated by a mixture } \\
\text { of independent and constrained } \\
\text { refinement }\end{array}$ \\
\hline$\Delta \rho_{\max }, \Delta \rho_{\min } /\left(\mathrm{e} \AA^{-3}\right)$ & $0.62,-0.64$ \\
\hline
\end{tabular}

refined on F2 with SHELXL $97 .^{48}$ All the non-hydrogen atoms were refined anisotropically and the hydrogen atoms were refined using a riding model. The aqua hydrogens were located in Fourier difference maps and the benzoquinoxaline hydrogens were generated geometrically.

\section{Calculations}

The structures of the quinoxalines were fully optimized using the B3LYP functional ${ }^{49,50}$ and the $6-311++G(d, p)$ basis set. Solvation effects were included using the polarizable continuum model with the CPCM method. ${ }^{51,52}$ All the optimized structures were confirmed as a local minimum on the potential energy surface by calculation of the Hessian matrix force constant (no negative eigenvector). All calculations were performed with the Gaussian 09W software..$^{53}$

\section{Results and Discussion}

\section{Synthesis and characterization of compounds 1-3}

The reaction of 2,3-dichloro-1,4-naphthoquinone and tert-butyl $\mathrm{N}$-(2-aminoethyl)carbamate under the conditions described in the literature for other amines ${ }^{42,46}$ yielded novel tert-butyl 2-(3-chloro-1,4-dioxo-1,4-dihydronaphthalen2-ylamino)ethylcarbamate $\mathbf{1}$ ( $70 \%$ after purification by $\mathrm{CC}$ ) as a red solid, soluble in common organic solvents but insoluble in water. It was characterized by analytical and spectroscopic data (see Experimental section and Figures S1-S3 in the Supplementary Information (SI) section). The ${ }^{1} \mathrm{H}$ NMR spectrum $\left(\mathrm{CDCl}_{3}\right)$ exhibits the expected peaks due to the carbamate methyl groups at $\delta 1.44$, the methylene hydrogens as two broad quartets at $\delta 3.97$ and 4.86 that result from the couplings with the respective neighboring $\mathrm{NH}$ hydrogens. The latter appear as broad peaks at $\delta 4.86$ and 6.50. The four signals in the $\delta 7.61-8.13$ region are due to the naphthoquinone ring hydrogens. The IR spectrum shows the N-H amide $\left(3373 \mathrm{~cm}^{-1}\right)$ and amine $\left(3338 \mathrm{~cm}^{-1}\right)$ bands, a broad intense naphthoquinone carbonyl band $\left(1669 \mathrm{~cm}^{-1}\right)$ and an unusually weak band associated with the carbamate $\mathrm{C}=\mathrm{O}$ stretching $\left(1648 \mathrm{~cm}^{-1}\right)$ possibly due to the formation of a N-H...O (carbamate) hydrogen bond, as observed in the $\mathrm{X}$-ray structure of the analogous compound derived from tert-butyl $\mathrm{N}$-(3-aminopropyl)carbamate. ${ }^{42}$

Under the conditions employed for $\mathrm{N}$-Boc deprotection $\left(\mathrm{CF}_{3} \mathrm{COOH} / \mathrm{CH}_{2} \mathrm{Cl}_{2}\right)$, the initial orange solution of compound 1 immediately turned purple. It was left under stirring in a closed flask for $24 \mathrm{~h}$. Depending on the conditions employed for the treatment of the 
dark purple solid obtained after solvent evaporation, 5-chloro-3,4-dihydrobenzo[f] quinoxalin-6(2H)-one 2 and 5-chlorobenzo[f]quinoxalin-6-ol $\mathbf{3}$ were isolated in varying yields (Scheme 1). Thus, treatment of the dark purple solid with saturated $\mathrm{Na}_{2} \mathrm{CO}_{3(\text { aq })}$ resulted in $\mathrm{CO}_{2}$ evolution and formation of known orange dihydrobenzoquinoxaline $2,{ }^{26}$ which was extracted with EtOAc, purified by $\mathrm{CC}$ and obtained in $86 \%$ yield. Under these conditions, trace amounts of quinoxaline 3 were also isolated from the column. When the purple EtOAc solution was treated with water instead, the solution color turned dark yellow. Purification of the organic extracts by $\mathrm{CC}$ as before gave pale yellow benzoquinoxaline $\mathbf{3}$ in up to $46 \%$ yield, besides 2 .

Both compounds have been fully characterized by analytical and spectroscopic data (see Experimental and SI sections), that confirmed their identity, and the novel compound $\mathbf{3}$ was also characterized by a single crystal XRD study.

The ${ }^{1} \mathrm{H}$ NMR data for dihydrobenzoquinoxaline 2 (Figures S5-S7 in the SI section) are in agreement with those previously reported ${ }^{26}$ and confirm that the compound exists as the keto-amine tautomer, both in $\mathrm{CDCl}_{3}$ and in $\mathrm{CD}_{3} \mathrm{OD}$. The ${ }^{13} \mathrm{C}$ NMR spectrum of $2\left(\mathrm{CDCl}_{3}\right.$, Figure $\mathrm{S} 8$ in the SI section) exhibits all the expected signals, those corresponding to $\mathrm{C} 4(\mathrm{C}=\mathrm{O})$ and $\mathrm{C} 1(\mathrm{C}=\mathrm{N})$, at $\delta 176.3$ and 152.2, respectively. The ATR-FTIR (attenuated total reflectance Fourier transform infrared spectroscopy) spectrum of $\mathbf{2}$ (Figure $\mathrm{S} 4$ in the SI section) indicates similar structure in the solid state. It shows the amine $v_{\mathrm{N}-\mathrm{H}}$ band, at $3324 \mathrm{~cm}^{-1}$, and the quinoxaline $v_{\mathrm{CO}}$ low intensity band, at $1604 \mathrm{~cm}^{-1}$, at lower frequency than previously reported $\left(1635 \mathrm{~cm}^{1-}\right)^{26}$ probably due to intermolecular hydrogen bonding. The presence of EtOAc $\left(v_{\mathrm{CO}}=1737 \mathrm{~cm}^{-1}\right)$ was confirmed by elemental analysis.

The ${ }^{1} \mathrm{H}$ NMR spectrum of benzoquinoxaline 3 in $\mathrm{CDCl}_{3}$ (Figures S10 and S11 in the SI section) shows hydrogens
$\mathrm{H} 11$ and $\mathrm{H} 12$ as a multiplet which is actually a partially superimposed pair of doublets at $\delta 7.82 ; \mathrm{H} 6 / \mathrm{H} 7$ appear at $\delta 8.37$ and 9.18 as multiplets, and $\mathrm{H} 5 / \mathrm{H} 8$ appear at $\delta$ 8.83 and 8.93 as doublets. A peak around $\delta 6.7$, attributed to the $\mathrm{OH}$ hydrogen, is absent in the spectra in $\mathrm{CD}_{3} \mathrm{OD}$ and DMSO- $d_{6}$ (Figure S12 and S13 in the SI section). The ${ }^{13} \mathrm{C}$ NMR (APT) spectrum of 3 in DMSO- $d_{6}$ (Figure S14 in the SI section) shows all the expected peaks and no evidence for the presence of the keto-amine tautomer in solution. The $\mathrm{OH}$ bonded to $\mathrm{C} 4$ appears at $\delta 151.0$, typically a phenol carbon chemical shift. The $\mathrm{sp}^{2} \mathrm{C} 1$ and $\mathrm{C} 2$ carbons bonded to the quinoxaline nitrogens appear at $\delta 140.0$ and 137.0, respectively.

The ATR-FTIR spectrum of microcrystaline $\mathbf{3}$ is shown in Figure S9 in the SI section. The spectrum exhibits a broad band centered around $3200 \mathrm{~cm}^{-1}$, attributed to $v_{\mathrm{O}-\mathrm{H}}$, but the $v_{\mathrm{C}=\mathrm{N}}$ band(s) could not be unambigously located in the spectrum, suggesting the presence of intermolecular hydrogen bonds. In order to investigate the solid state structure of $\mathbf{3}$, an XRD study was carried out and the results are described below.

\section{Molecular and crystal structure of $\mathbf{3}$}

Crystals suitable for an XRD study were obtained by slow evaporation of an ethanol solution of $\mathbf{3}$. The $\mathrm{X}$-ray structure analysis of $\mathbf{3}$ revealed the enol-imine tautomer, shown in Figure 3a. Selected bond lengths and angles are also given in Figure $3 \mathrm{a}$. As suggested by the IR spectrum, this tautomer is stabilized by hydrogen bonds $[\mathrm{O}(1)-\mathrm{H}(1) \ldots \mathrm{O}(1 \mathrm{w})$ and $\mathrm{O}(2 \mathrm{w})-\mathrm{H}(1 \mathrm{w} 2) \ldots \mathrm{N}(1)]$ (Figure $3 b$ ). To our knowledge, this is the first example of a structurally characterized molecule containing the benzo[f]quinoxalin-6-ol nucleus.

The compound crystallizes in the $\mathrm{P} 2_{1} / \mathrm{n}$ space group with three independent water molecules in the asymmetric

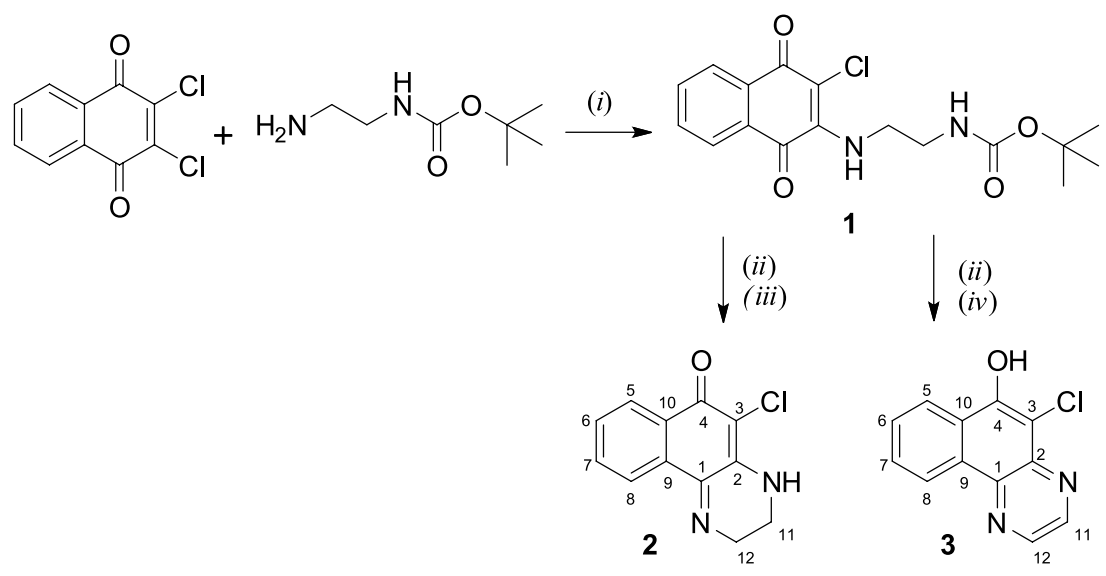

Scheme 1. Reactants and conditions: (i) $\mathrm{K}_{2} \mathrm{CO}_{3}, \mathrm{MeCN}$, reflux, $5 \mathrm{~h}$, (ii) $\mathrm{CF}_{3} \mathrm{COOH}, \mathrm{CH}_{2} \mathrm{Cl}_{2}, 24 \mathrm{~h}$, room temperature, (iii) sat. $\mathrm{Na}_{2} \mathrm{CO}_{3(\text { aq }} / \mathrm{EtOAc}$ extraction, $\mathrm{CC}$ and (iv) $\mathrm{H}_{2} \mathrm{O} /$ EtOAc extraction, $\mathrm{CC}$. 


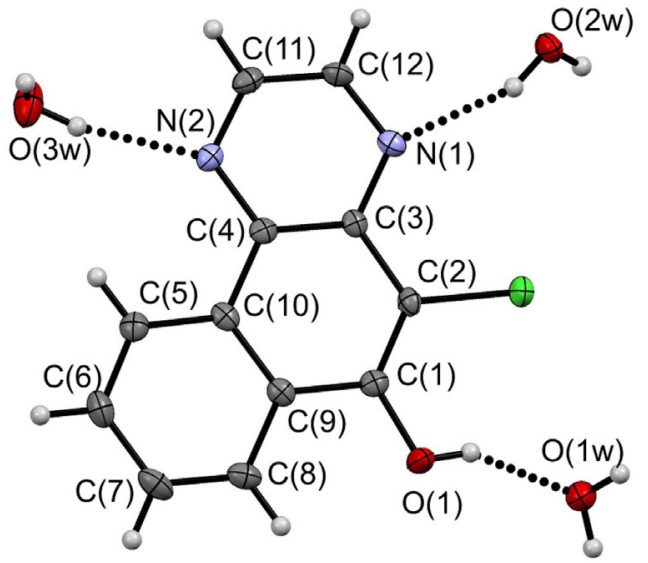

(a)

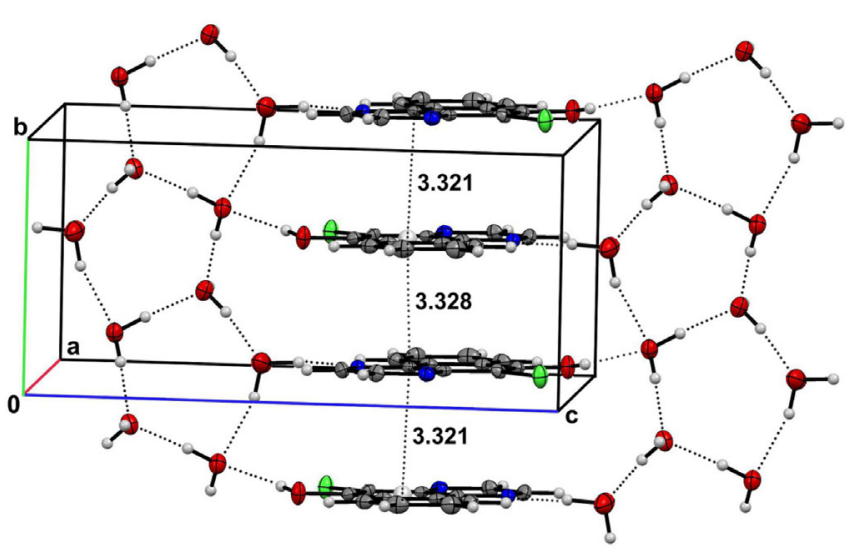

(b)

Figure 3. (a) ORTEP view of $\mathbf{3}$ with the crystallographic atom numbering scheme. Non-hydrogen atom displacement ellipsoids are drawn at the 50\% probability level; (b) view showing the hydrogen bond interactions between the water molecules chain and the $\pi$-stacked benzoquinoxaline rings. Selected geometric parameters are as follows: bond distances (Å): C11-C2 1.729 (3), O1-C1 1.351 (3), C3-N1 1.359 (4), C3-C4 1.412 (4), C3-C2 1.431 (4), C1-C2 1.365 (4), C1-C9 1.442 (4), N1-C12 1.317 (4) C10-C5 1.410 (4), C10-C9 1.410 (4), C10-C4 1.447 (4), N2-C11 1.323 (4), N2-C4 1.358 (3), C8-C7 1.369 (4), C8-C9 1.411 (4), C11-C12 1.387 (4), C5-C6 1.370 (4) C6-C7 1.398 (4) and bond angles (degree): N1-C3-C4 121.2 (2), N1-C3-C2 119.6 (3), O1-C1-C2 125.0 (3), O1-C1-C9 114.4 (2), C12-N1-C3 116.2 (3), C11-N2-C4 116.8 (3), N2-C11-C12 122.1 (3), C1-C2-Cl1 120.1 (2). Tables S1 and S2 (in the SI section) contain the full list of bond distances and angles.

unit. It exhibits a planar structure with all ring atoms $\mathrm{sp}^{2}$ hybridized and bond distances and angles typical of conjugated $\pi$-systems (see Tables S1 and S2 in the SI section). ${ }^{21,22}$ The benzoquinoxalines are packed in an ABAB pattern formed by $\pi-\pi$ interactions and hydrogen bonds along the $b$-axis (Figure $3 \mathrm{~b}$ ). The interactions between the water molecules result in double chains of packed molecules. These chains are interconnected by benzoquinoxaline molecules along the 2(1) screw axis. The observed distances between the parallel $\pi$-stacked benzoquinoxaline rings are shorter than $3.4 \AA .{ }^{54}$ Other interactions between benzoquinoxalines and water molecules $\left\{\left[\mathrm{Q} \ldots \mathrm{O}(1 \mathrm{w}) \ldots \mathrm{O}(2 \mathrm{w})^{1 / 2+\mathrm{x}, 1 / 2-\mathrm{y}, 1 / 2+\mathrm{z}} \ldots \mathrm{O}(3 \mathrm{w})^{\mathrm{x}, \mathrm{y}, 1+\mathrm{z}} \ldots \mathrm{Q}^{\mathrm{x}, \mathrm{y}, 1+\mathrm{z}}\right]\right.$

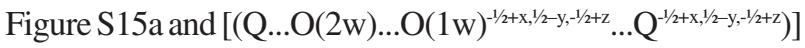
Figure S15b and Table S3 in the SI section \} result in the packing along the $c$-axis and [101] direction, respectively, and stabilize the 3D crystalline arrangement.

\section{Mechanistic aspects of the dehydrogenation of 2}

Pure dihydrobenzoquinoxaline 2 is air-stable in $\mathrm{CH}_{2} \mathrm{Cl}_{2}$ solution in the absence of acid. Nevertheless, it undergoes slow dehydrogenation when chromatographed on a silica gel column with the same solvent system used for its purification (see Experimental section and Figure 4).

Kallmayer and Seyfang ${ }^{43}$ reported in the eighties that related dihydrobenzo[f]quinoxalin-6(2H)-ones (with $\mathrm{R}=\mathrm{CH}_{3}, \mathrm{OCH}_{3}, \mathrm{CN}$ and $\mathrm{NHAc}$ in place of $\mathrm{Cl}$ ) also undergo dehydrogenation to the respective benzoquinoxalin-6-ol compounds analogous to $\mathbf{3}$. When promoted by base, the products were obtained in high yields. The acid promoted reaction (aqueous $\mathrm{HCl} / \mathrm{EtOH}$ solution), however, gave only trace amounts of the benzoquinoxalin-6-ol derivatives besides the respective hydrolysis products, 2-hydroxy-3-R1,4-naftoquinones. The mechanism for the acid promoted dehydrogenation was suggested to involve, as the first step, reversible protonation of the carbonyl group, followed by proton migration and, presumably, $\mathrm{H}_{2}$ elimination (see Figure S16 in the SI section). ${ }^{43}$

Herein, we suggest that the dark purple product formed under the conditions used for the $N$-Boc deprotection of $\mathbf{1}$ is the protonated form of the dihydrobenzoquinoxaline 2 proposed by Kallmayer and Seyfang ${ }^{43}$ (see Scheme 2). In other words, nucleophilic attack of the deprotected amine at the carbonyl carbon atom to yield $\mathbf{2}$ is a facile process. Moreover, purple protonated $\mathbf{2}$ is stable in $\mathrm{CH}_{2} \mathrm{Cl}_{2} / \mathrm{CF}_{3} \mathrm{COOH}$. This would account for the fact that when this purple species is treated with base, the dihydrobenzoquinoxaline $\mathbf{2}$ is formed in good yields (see Scheme 1), but under acid conditions, in the presence of water, the reaction proceeds to give the dehydrogenated product 3 .

Relative energies of a series of dihydrobenzoquinoxalines and benzoquinoxalines tautomers related to 2 and $\mathbf{3}$

Benzophenazines (e.g., Figure 1a) and dihydrobenzoquinoxalines can exist in either the keto-amine form, such as 2 (see Figure 1b), or in the enol-imine form exhibited by 3 . In view of our continuing interest in the tautomerism of naphthoquinone derived compounds, $38,55,56$ we decided to undertake a detailed investigation of the 
(b)

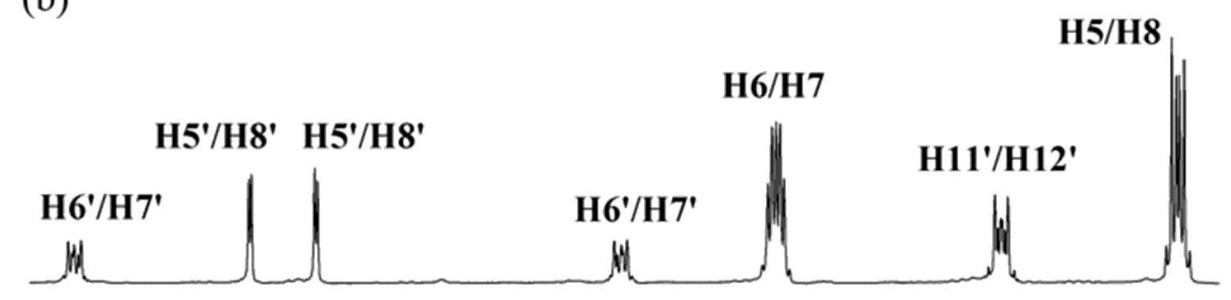

(a)<smiles></smiles>

2<smiles>Oc1c(Cl)c2ccccc2c2nccnc12</smiles>

3

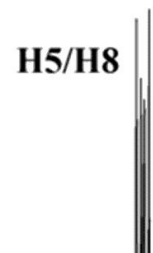

H6/H7

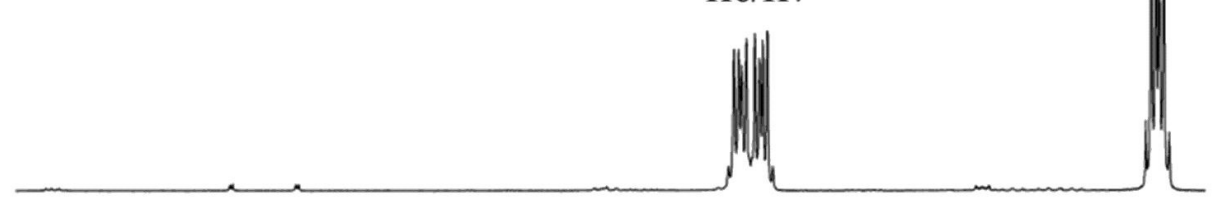

\begin{tabular}{|c|c|c|c|c|c|c|c|c|}
\hline$T$ & $T$ & $T$ & $T$ & $T$ & $T$ & $T$ & $T$ & $T$ \\
\hline 9.2 & 9.0 & 8.8 & 8.6 & 8.4 & 8.2 & 8.0 & 7.8 & 7.6 \\
\hline
\end{tabular}

Figure 4. (a) ${ }^{1} \mathrm{H} \mathrm{NMR}(500 \mathrm{MHz})$ spectrum of 2 in $\mathrm{CDCl}_{3}$ (obtained after neutralization of the crude solid with saturated $\mathrm{Na}_{2} \mathrm{CO}_{3(\mathrm{aq})}$, extraction with EtOAc and purification by flash chromatography-hexane/EtOAc, $10 / 1$ to $2 / 1, \mathrm{v} / \mathrm{v})$; (b) ${ }^{1} \mathrm{H} \mathrm{NMR}(500 \mathrm{MHz})$ spectrum of 2 in $\mathrm{CDCl}_{3}$ after flash chromatography showing formation of $\mathbf{3}$.

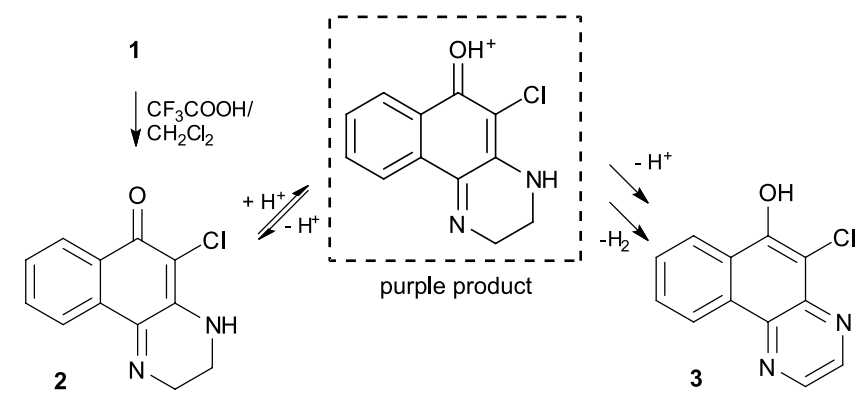

Scheme 2. Proposed path for the formation of $\mathbf{2}$ and $\mathbf{3}$ from tert-butyl 2-(3-chloro-1,4-dioxo-1,4-dihydronaphthalen-2-ylamino)ethylcarbamate 1.30

relative energies of the tautomers of $\mathbf{2}$ and tautomers of 3 and of several related compounds. In addition, it was also investigated possible correlations, e.g., with the nature of the substituent at position 3 and the extension of aromaticity. Solvation effects using the polarizable continuum solvation approach were included to investigate the effect of non-polar $\left(\mathrm{CHCl}_{3}\right)$, polar protic $\left(\mathrm{CH}_{3} \mathrm{OH}\right)$ and polar aprotic (DMSO) solvents.

From the two alternative conformations for the hydroxyl hydrogen of the enol-imine tautomer of compounds 2 and 3 and of related compounds containing $\mathrm{H}$ or $\mathrm{CH}_{3}$ in place of the $\mathrm{Cl}$ atom at position 3 , the most stable is that in which the hydroxyl hydrogen atom is directed towards the substituent.
This conformation is the one adopted in the solid state structure of $\mathbf{3}$ (see Figure 3a and Table S4 in the SI section). Therefore, all computational results reported below are for this conformation. Calculated bond lengths and angles for $\mathbf{3}$ are in good agreement with the experimental (XRD) data (see Tables S1 and S2 in the SI section).

The relative energies calculated at the B $3 \mathrm{LYP} /$ $6-311++\mathrm{G}(\mathrm{d}, \mathrm{p})$ level for the tautomers of the dihydrobenzoquinoxalines, benzoquinoxalines and benzophenazines are given in Table 2 . All values reported were obtained by subtracting the energy of the keto-amine form from that of the enol-imine one, i.e., the more negative the value, the more stable the enol-imine tautomer and vice-versa. 
Table 2. B3LYP/6-311++G(d,p) relative energies $\left(\mathrm{kcal} \mathrm{mol}^{-1}\right)$ calculated for the two tautomers of dihydrobenzoquinoxalines, benzoquinoxalines and benzophenazines. The energy values were calculated as $\mathrm{E}_{\text {enol-imine }}-\mathrm{E}_{\text {keto-amine }}$ forms
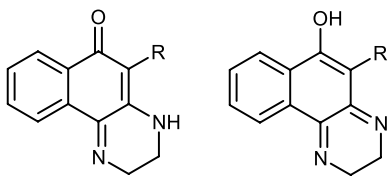

Dihydrobenzoquinoxalines

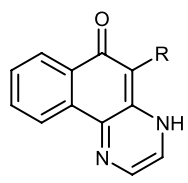

Benzoquinoxalines

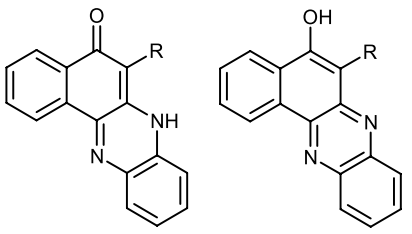

Benzophenazines

\begin{tabular}{|c|c|c|c|c|c|c|c|c|c|}
\hline \multirow{2}{*}{ Solvent $(\varepsilon)^{\mathrm{a}}$} & \multicolumn{9}{|c|}{$\mathrm{R}=$} \\
\hline & $\mathrm{H}$ & $\mathrm{Cl}(\mathbf{2})$ & $\mathrm{CH}_{3}$ & $\mathrm{H}$ & $\mathrm{Cl}(\mathbf{3})$ & $\mathrm{CH}_{3}$ & $\mathrm{H}$ & $\mathrm{Cl}$ & $\mathrm{CH}_{3}$ \\
\hline Gas phase & 11.70 & 12.13 & 12.53 & -9.78 & -8.15 & -8.56 & -2.69 & -1.61 & -1.06 \\
\hline $\mathrm{CHCl}_{3}(4.7)$ & 13.50 & 14.35 & 14.21 & -5.20 & -3.66 & -4.48 & 0.37 & 1.56 & 1.21 \\
\hline $\mathrm{CH}_{3} \mathrm{OH}(36.2)$ & 14.31 & 15.25 & 14.92 & -3.46 & -1.96 & -2.92 & 1.52 & 2.71 & 2.21 \\
\hline DMSO (46.8) & 14.36 & 15.31 & 14.96 & -3.35 & -1.86 & -2.83 & 1.59 & 2.78 & 2.27 \\
\hline
\end{tabular}

an parenthesis is given the value of the dielectric constant $(\varepsilon)$ of each solvent.

For the dihydrobenzoquinoxaline series (Table 2), the keto-amine tautomer is by far the most stable form, independent of the substituent and solvent. These results are in agreement with the experimental data, both in the solid state and in solution (see Experimental and reference 26).

For the benzoquinoxaline series, the relative energy of the enol-imine tautomer is lower than that of the keto-amine tautomer. For the tautomers of the structurally related benzophenazines, which contain an additional benzene fused to the pyrazine ring, the gas phase relative energies also indicate the enol-imine tautomer as the most stable one, although less so than in the benzoquinoxaline series (Table 2). The different substituents $\left(\mathrm{R}=\mathrm{H}, \mathrm{Cl}\right.$ or $\left.\mathrm{CH}_{3}\right)$ have only marginal effect on the relative energies. However, in all cases, the $\mathrm{Cl}$ and $\mathrm{CH}_{3}$ substituents decrease the relative stabilities of the enol-imine forms as compared to $\mathrm{R}=\mathrm{H}$.

Solvation has a strong effect on the relative stabilities, with the more polar DMSO and $\mathrm{CH}_{3} \mathrm{OH}$ solvents having a higher effect than the less polar $\mathrm{CHCl}_{3}$. The three solvents preferentially stabilize the keto-amine tautomers, mainly because these tautomers have higher dipole moments than the enol-imine tautomers (see Table S5 in the SI section, e.g., $|\mu|(D)=5.45 \times 1.61(2)$ and $5.95 \times 1.19(3)$, respectively) The preferential stabilization of the keto-amine form by the solvent is enough to reverse the stability order in the case of the benzophenazines. For the latter compounds, the keto-amine form, which is the least stable in the gas phase, becomes the most stable in all solvents. The relative effect of the solvents follows the corresponding dielectric constant order (Table 2), with $\mathrm{CH}_{3} \mathrm{Cl}<\mathrm{CH}_{3} \mathrm{OH} \sim$ DMSO. In summary, in the gas-phase, dihydrobenzoquinoxalines are most stable as the keto-amine tautomer, while for the benzoquinoxalines and benzophenazines the enol-imine forms are the most stable. The three solvents studied reverse the stability order for the benzophenazines, making them more stable in the keto-amine form.

These results agree with the ${ }^{1} \mathrm{H}$ and ${ }^{13} \mathrm{C}$ NMR spectra of $\mathbf{3}$ obtained in the three (deuterated) solvents (see Figures S10-S14 in the SI section) and the ${ }^{1} \mathrm{H}$ NMR spectrum of the $\mathrm{CH}_{3}$ substituted derivative reported in $\mathrm{CDCl}_{3}{ }^{43}{ }^{4}$ They indicate, therefore, that the relative stabilities of the two tautomers are dominated by the extent of aromaticity in the benzoquinoxaline series. However, this aspect seems to be less important for the benzophenazines, making the solvent more relevant in this case.

The ${ }^{13} \mathrm{C}$ NMR spectrum of the unsubstituted benzophenazine $(\mathrm{R}=\mathrm{H})$ in DMSO- $d_{6}(\delta 206.4 \mathrm{ppm})$ has been interpreted in terms of the keto-amine tautomer in agreement with the relative energies reported above (Table 2) ${ }^{23} \mathrm{In} \mathrm{CDCl}_{3} / \mathrm{CF}_{3} \mathrm{COOD}(\delta 168.7 \mathrm{ppm})$, however, the enol-imine tautomer was proposed as the most stable, differently from the prediction based on the relative energies. ${ }^{44}$ In $\mathrm{CHCl}_{3}$ the energy difference between the two tautomers for this derivative is very low, only $0.37 \mathrm{kcal} \mathrm{mol}^{-1}$ in favor of the keto-amine tautomer, certainly below the accuracy of the theoretical method employed. To see whether this could be accounted for by the entropic and thermal contributions to the equilibrium, it was also calculated the relative Gibbs free energies of the two tautomers at $298 \mathrm{~K}$ (Table S6 in the SI section). The Gibbs free energy difference between the two tautomers is reduced to $0.22 \mathrm{kcal} \mathrm{mol}^{-1}$, still favoring the keto-amine tautomer, thus suggesting that both tautomers may be present under equilibrium conditions.

To look for the origin of the difference between the computed relative energies and the main tautomer found 
in solution for this benzophenazine, we simulated the ${ }^{13} \mathrm{C}$ NMR spectra of the two tautomers of this compound (Tables S7-S11 in the SI section). For the dihydrobenzoquinoxaline 2, which exists mainly as the keto-amine tautomer $(\delta 176.3$ $\mathrm{ppm}$ ), and the benzoquinoxaline $\mathbf{3}$, which exists mainly as the enol-imine tautomer ( $\delta 151.0 \mathrm{ppm})$, the $\mathrm{C} 4$ carbon chemical shifts (in $\mathrm{CDCl}_{3}$ ) are good probes to distinguish between the two tautomers in solution.

The calculated $\mathrm{C} 4$ carbon chemical shift of the benzophenazine keto-amine tautomer $(\delta 188.6 \mathrm{ppm})$ agrees (to within $8.6 \%$ ) with the experimental value in DMSO- $d_{6}$ (Table 3 ). However, the $\mathrm{C} 4$ carbon chemical shift measured in $\mathrm{CDCl}_{3} / \mathrm{CF}_{3} \mathrm{COOD}(\delta 168.7 \mathrm{ppm})$ has a much lower value, indicating the prevalence of the enol-imine tautomer in this solvent. Indeed, the computed value for the $\mathrm{C} 4$ carbon chemical shift of this tautomer agrees with the experimental data to within $2.7 \%$. Nevertheless, the experimental spectrum in $\mathrm{CDCl}_{3}$ was obtained in the presence of $\mathrm{CF}_{3} \mathrm{COOD},{ }^{44}$ which could protonate either the keto-amine or the enol-imine tautomer, leading in each case to the same structure with an $\mathrm{OH}$ bond, typical of the enol-imine tautomer. Calculation of the C4-carbon chemical shift for the protonated structure (optimized from the protonation of both tautomers, see data in Table 3) confirms that in $\mathrm{CDCl}_{3} / \mathrm{CF}_{3} \mathrm{COOD}$, the experimental value is close to that found for the enol-imine tautomer. Therefore, in this solvent system, the experimental data accounts for either the protonated benzophenazine or the enol-imine tautomer.

The reported ${ }^{13} \mathrm{C}$ NMR data for benzophenazine derivatives substituted at position 15 (see Figure 1a, g, $\mathrm{R}^{5}=\mathrm{OMe}, \mathrm{Cl}$ and $\left.\mathrm{NO}_{2}\right)$ in DMSO- $d_{6}(\delta 206.4$ for all compounds $)^{23}$ also agree with the proposed keto-amine tautomer.
Likewise, the same keto-amine structure has been proposed in the literature for the 3-isopentyl- and 3-isobutyl-substituted benzophenazines ${ }^{22}$ (see Table 3) in spite of the very different $\mathrm{C} 4$-carbon chemical shifts observed in the spectra of the two compounds in DMSO- $d_{6}$ ( $\mathrm{R}=$ isopentyl, $\delta 198.6 ; \mathrm{R}=$ isobutyl, $\delta 152.6 \mathrm{ppm})$. As discussed above, chemical shifts in the $160-170$ ppm range are typical for the enol-imine tautomer. It is suggested, therefore, that the observed chemical shift of $\delta 152 \mathrm{ppm}$ for the isobutyl substituted derivative indicates prevalence of the enol-imine tautomer for this derivative (see Tables S12-S15). This unexpected result might arise from intermolecular association which has been reported to lead to protomeric equilibrium shift in similar compounds. ${ }^{57,58}$ Studies of concentration effects on C4-carbon chemical shifts of this class of compounds would shed some light on the problem.

\section{Conclusions}

In the present study, we report on the tautomeric equilibrium in benzo[f]quinoxalin-6(4H)-ones derived from the 1,4-naphthoquinone nucleus. XRD analysis and DFT calculations confirm the enol-imine tautomer as the most stable form of these benzoquinoxalines. The higher stability of the enol-imine tautomer for these derivatives has been attributed to enhanced aromaticity in the enol-imine tautomeric form. For the enol-imine tautomer of dihydrobenzoquinoxalines, aromatization of the additional ring does not occur, which makes the keto-amine tautomer much more stable. This fact was also confirmed by means of the $\mathrm{C} 4$-carbon atom ${ }^{13} \mathrm{C}$ chemical shift. The chemical shift of this carbon was employed as a probe to conclude that benzo $[a]$ phenazin-5(7H)-one exists mainly in the

Table 3. ${ }^{13} \mathrm{C}$ NMR experimental and calculated $\mathrm{C} 4$ chemical shifts ( $\delta$ in ppm) for selected benzophenazines (see Tables S8-S16 in the SI section)

\begin{tabular}{|c|c|c|c|}
\hline $\mathrm{R}$ & $\begin{array}{c}\text { Keto-amine } \\
\delta \text { calc. (exp.) / ppm }\end{array}$ & $\begin{array}{c}\text { Enol-imine } \\
\delta \text { calc. (exp.) } / \mathrm{ppm}\end{array}$ & $\begin{array}{l}\text { Protonated structure } \\
\delta \text { calc. (exp.) / ppm }\end{array}$ \\
\hline $\mathrm{H}^{\mathrm{a}, 23}$ & $188.6(206.4)$ & 165.4 & \\
\hline $\mathrm{H}^{\mathrm{b}, 44}$ & & $(\underline{168.7})$ & $176.3(\underline{168.7})$ \\
\hline $\mathrm{H}^{\mathrm{c}}$ & 187.9 & 164.2 & \\
\hline isobutyl $1^{\mathrm{a}, 22}$ & 187.6 & $162.3(152.6)$ & \\
\hline isopenty $1^{\mathrm{a}, 22}$ & $187.3(198.6)$ & 162.9 & \\
\hline
\end{tabular}

${ }^{\mathrm{a}}$ In DMSO (d $\mathrm{d}_{6}$-DMSO); ${ }^{\text {in }} \mathrm{CHCl}_{3}\left(\mathrm{CDCl}_{3} / \mathrm{CF}_{3} \mathrm{COOD}\right)$; ${ }^{\text {in }} \mathrm{CHCl}_{3}$. 
keto-amine form in DMSO, whereas in $\mathrm{CHCl}_{3} / \mathrm{CF}_{3} \mathrm{COOH}$, it exists mainly as the enol-imine form, although the B3LYP/6-311++G(d,p) calculations with inclusion of the solvent effects give a slight $\left(0.22 \mathrm{kcal} \mathrm{mol}^{-1}\right)$ preference for the keto-amine tautomer.

\section{Supplementary Information}

Supplementary information associated with this paper contains IR and NMR spectra $\left({ }^{1} \mathrm{H}\right.$ and $\left.{ }^{13} \mathrm{C}\right), \mathrm{X}$-ray structural parameters of $\mathbf{3}$ and the results of the theoretical calculations. These data are available free of charge at http://jbcs.sbq.org.br as PDF file. Crystallographic data for the structural analysis of compound $\mathbf{3}$ have been deposited with the Cambridge Crystallographic Data Center, CCDC No. 908496. Copies of this information may be obtained free of charge from CCDC, 12 Union Road, Cambridge, CB2 1EZ, UK.

\section{Acknowledgments}

The authors thank the Brazilian agencies Conselho Nacional de Desenvolvimento Científico e Tecnológico (CNPq), Coordenação de Aperfeiçoamento de Pessoal de Nível Superior (CAPES) and Fundação de Amparo à Pesquisa do Estado do Rio de Janeiro (FAPERJ) for financial support. FAPERJ-PRONEX (E-26/171.512.2010) is acknowledged. M. D. V. and J. W. M. C. are recipients of CNPq research fellowships. The authors thank LabCri at Universidade Federal de Minas Gerais, Brazil, for XRD data collection.

\section{References}

1. Welsch, M. E.; Snyder, S. A.; Stockwell, B. R.; Curr. Opin. Chem. Biol. 2010, 14, 347. 2.

2. Romeiro, N. C; Aguirre, G.; Hernández, P.; González, M.; Cerecetto, H.; Aldana, I.; Pérez-Silanes, S.; Monge, A.; Barreiro, E. J.; Lima, L. M.; Bioorg. Med. Chem. 2009, 17, 641.

3. Neves-Pinto, C.; Malta, V. R.; Pinto, M. C. F. R.; Santos, R. H.; De Castro, S. L.; Pinto, A. V.; J. Med. Chem. 2002, 45, 2112.

4. de Andrade-Neto, V.; Goulart, M.; da Silva Filho, J.; da Silva, M.; Pinto, M.; Pinto, A.; Zalis, M.; Carvalho, L.; Krettli, A.; Bioorg. Med. Chem. Lett. 2004, 14, 1145.

5. Guillon, J.; Mouray, E.; Moreau, S.; Mullié, C.; Forfar, I.; Desplat, V.; Belisle-Fabre, S.; Pinaud, N.; Ravanello, F.; LeNaour, A.; Léger, J.-M.; Gosmann, G.; Jarry, C.; Déléris, G.; Sonnet, P.; Grellier, P.; Eur. J. Med. Chem. 2011, 46, 2310.

6. Kumara, K. S.; Rambabua, D.; Sandra, S.; Kapavarapu, R.; Krishna, G. R.; Rao, M. V. B; Chatti, K.; Reddy, C. M.; Misra, P.; Pal, M.; Bioorg. Med. Chem. 2012, 20, 1711.
7. Carneiro, P. F.; Pinto, M. C. F. R.; Coelho, T. S.; Cavalcanti, B. C.; Pessoa, C.; de Simone, C. A.; Nunes, I. K. C.; de Oliveira, N. M.; de Almeida, R. G.; Pinto, A. V.; de Moura, K. C. G.; da Silva, P. A.; da Silva Júnior, E. N.; Eur. J. Med. Chem. 2011, 46, 4521.

8. Ghadage, R. V.; Shirote, P. J.; J. Chem. Pharm. Res. 2011, 3, 260.

9. Hazeldine, S.; Polin, L.; Kushner, J.; Paluch, J.; White, K.; Edelstein, M.; Palomino, E.; Corbett, T.; Horwitz, P.; J. Med. Chem. 2001, 44, 1758.

10. Wu, P.; Su, Y.;Guan, X.; Liu, X.; Zhang, J.; Dong, X.; Huang, W.; Hu, Y.; PloS One 2012, 7, e43171.

11. Chena, Q.; Bryanta,V. C; Lopez, H.; Kelly, D. L; Luo, X.; Natarajan, A.; Bioorg. Med. Chem. Lett. 2011, 21, 1929.

12. Ries, U. J.; Priekpe, H. W.; Hauel, N. H.; Handschuh, S.; Mihm, G.; Stassen, J. M.; Wienen, W.; Nar, H.; Bioorg. Med. Chem. Lett. 2003, 13, 2297.

13. Kleim, J. P.; Bender, R.; Billhardt, U. M.; Meichsner, C.; Riess, G.; Rösner, M.; Winkler, I.; Paessens, A.; Antimicrob. Agents Chemother. 1993, 37, 1659.

14. Son, H.; Han, W.; Wee, K.; Yoo, D.; Lee, J.; Kwon, S.; Ko, J.; Kang, S.; Org. Lett. 2008, 10, 5401.

15. Mancilha, F.; Neto, B.; Lopes, A.; Moreira Jr, P.; Quina, F.; Gonçalves, R.; Dupont, J.; Eur. J. Org. Chem. 2006, 21,4924.

16. Kudo, K; Momotake, A.; Kanna, Y.; Nishimura, Y.; Arai, T.; Chem. Commun. 2011, 47, 3867.

17. Ozdemir, S.; Sendur, M.; Oktem, G.; Dogan, O.; Toppare, L.; J. Mater. Chem. 2012, 22, 4687.

18. Beaudoin, D. S.; Obare, S. O.; Tetrahedron Lett. 2008, 49, 6054.

19. Zapata, F.; Caballero, A.; Molina, P.; Tarraga A.; Sensors 2010 , $10,11311$.

20. Wu, C.-D.; Lu, C.-Z.; Zhuang, H.-H.; Huang J.-S.; Inorg. Chem. 2002, 41, 5636.

21. da Silva, M.; Pinto, M.; de Simone, C.; Soares, J.; Reys, J.; de Souza Filho, J.; Harrison, W.; Carvalho, C.; Goulart, M.; da Silva Júnior, E.; Pinto, A.; Tetrahedron Lett. 2011, 52, 2415.

22. Carneiro, P.; Pinto, M.; Coelho, T.; Cavalcanti, B.; Pessoa, C.; de Simone, C.; Nunes, I.; Oliveira, M.; Almeida, R.; Pinto, A.; de Moura, K.; da Silva, P.; da Silva Júnior, E.; Eur. J. Med. Chem. 2011, 46, 4521.

23. Rehberg, G. M.; Rutherford, J. L.; J. Heterocycl. Chem. 1995, $32,1643$.

24. Santos, M. D. F.; Litivack-Junior, J. T.; Antunes, R. V.; Silva, T. M. S.; Camara, C. A.; J. Braz. Chem. Soc. 2011, 22, 796.

25. Kallmayer, H.-J.; Arch. Pharm. 1974, 307, 806.

26. Kallmayer, H.-J.; Seyfang, K.; Arch. Pharm. 1980, 313, 603.

27. Kallmayer, H.-J.; Seyfang, K.; Arch. Pharm. 1984, 317, 743.

28. Kallmayer, H.-J.; Seyfang, K.; Arch. Pharm. 1984, 317, 855.

29. Kallmayer, H.-J.; Seyfang, K.; Arch. Pharm. 1984, 317, 329.

30. Kallmayer, H.-J.; Seyfang, K.; Arch. Pharm. 1985, 318, 360.

31. Kallmayer, H.-J.; Seyfang, K.; Arch. Pharm. 1985, 318, 607.

32. Kallmayer, H.-J.; Seyfang, K.; Arch. Pharm. 1986, 319, 52. 
33. Kallmayer, H.-J.; Seyfang, K.; Dtsch. Apoth. Ztg. 1983, 123, 2147.

34. Kallmayer, H.-J.; Seyfang, K.; Arch. Pharm. 1986, 319, 52.

35. Cunha, A. S.; Lima, E. L. S.; Pinto, A. C.; Esteves-Souza, A.; Echevarria, A.; Camara, C. A.; Vargas, M. D.; Torres, J. C.; J. Braz. Chem. Soc. 2006, 17, 439.

36. Esteves-Souza, A.; Figueiredo, D. V.; Esteves, A.; Câmara, C. A.; Vargas, M. D.; Pinto, A. C.; Echevarria, A.; Braz. J. Med. Biol. Res. 2007, 40, 1399.

37. Cunha, A. S.; Vargas, M. D.; Gattass, C. R.; Pinto, A. C.; Camara, C. A.; Esteves, A. S.; Lima, E. L. S.; Oncol. Rep. 2008, $20,225$.

38. Francisco, A. I.; Casellato, A.; Neves, A. P.; Carneiro, J. W. D.; Vargas, M. D.; Visentin, L. C.; Magalhães, A.; Câmara, C. A.; Pessoa, C.; Costa-Lotufo, L. V.; Marinho Filho, J. D. B.; de Moraes, M. O.; J. Braz. Chem. Soc. 2010, 21, 169.

39. Neves, A. P.; Maia, K. C. B.; Vargas, M. D.; Visentin, L. C.; Casellato, A.; Novak, M. A.; Mangrich, A. S.; Polyhedron 2010, 29,2884

40. Neves, A. P.; Barbosa, C. C.; Greco, S. J.; Vargas, M. D.; Visentin, L. C.; Pinheiro, C. B.; Mangrich, A. S.; Barbosa, J. P.; da Costa, G. L.; J. Braz. Chem. Soc. 2009, 20, 712.

41. Neves, A. P.; Silva, G. B., Vargas, M. D.; Pinheiro, C. B.; Visentin, L. C.; Marinho Filho, J. D. B.; Araújo, A. J.; CostaLotufo, L. V.; Pessoa, C.; Moraes, M. O.; Dalton Trans. 2010, 39, 10203.

42. Resende, J. A. L. C.; Gomez, J. A.; Acta. Cryst. 2012, E68, o2361.

43. Kallmayer, H.-J.; Seyfang, K.; Arch. Pharm. 1985, 318, 865

44. Kaupp, G.; Naimi-Jamal, M. R.; Eur. J. Org. Chem. 2002, 1368.

45. Duclos, S.; Stoeckli-Evans, H.; Ward, T.; Helv. Chim. Acta, 2001, 28, 3148.

46. Tandon, V. K.; Maurya, H. K.; Mishra, N. N.; Shukla, P. K.; Eur. J. Med. Chem. 2009, 44, 3130.

47. Agilent Technologies; CrysAlisPro Software System, version 1.171.35.21, Xcalibur CCD System; Agilent Technologies UK Ltd.: Oxford, UK, 2011,.

48. Sheldrick, G. M.; Acta Cryst. 2008, A64, 112.

49. Becke, A. D.; J. Chem. Phys. 1996, 104, 1040.
50. Lee, C.; Yang, W.; Parr, R. G.; Phys. Rev. B 1988, 37, 785.

51. Barone. V.; Cossi, M.; J. Phys. Chem. A 1998, 102, 1995.

52. Cossi, M.; Rega, N.; Scalmani, G.; Barone, V.; J. Comput. Chem. 2003, 24, 669

53. Frisch, M. J.; Trucks, G. W.; Schlegel, H. B.; Scuseria, G. E.; Robb, M. A.; Cheeseman, J. R.; Montgomery, J. A.; Vreen Jr., T.; Kudin, K. N.; Burat, J. C.; Millam, J. M.; Iyengar, S. S.; Tomsi, J.; Barone, V.; Mennucci, B.; Cossi, M.; Scalmani, G.; Rega, N.; Petersson, G. A.; Nakatsuji, H.; Hada, M.; Ehara, M.; Toyota, K.; Fukua, R.; Hasegawa, J.; Ishida, M.; Nakajim, T.; Honda, Y.; Kitao, O.; Nakai, H.; Klene, M.; Li, X.; Knox, J. E.; Hratchian, H. P.; Cross, J. B.; Adamo, C.; Jaramillo, J.; Gomperts, R.; Stratmann, R. E.; Yazyev, O.; Austin, A. J.; Cammi, R.; Pomelli, C.; Ochteski, J. W.; Ayala, P. Y.; Morokuma, K.; Voth, G. A.; Salvador, P.; Dannenberg, J. J.; Zakrzewski, V. G.; Dapprich, S.; Daniels, A. D.; Strain, M. C.; Faras, O.; Malick, D. K.; Rabu, A. D.; Raghavachari, K.; Foresman, J. B.; Ortiz, J. V.; Cui, Q.; Baboul, A. G.; Clifford, S.; Cioslowski, J.; Stefanov, B. B.; Liu, G.; Liashenko, A.; Piskorz, P.; Komaromi, I.; Martin, R. L.; Fox, D. J.; Keith, T.; Al-Laham, M. A.; Peng, C.; Nanayakkra, A.; Challacombe, M.; Gill, P. M. W.; Johnson, B.; Chen, W.; Wong, M. W.; Gonzalez, C.; Pople, J. A.; Gaussian 03, Revision B.02, Gaussian, Inc.: Pittsburg, P.A., USA, 2003.

54. Hunter, C. A.; Sanders, J. K. M.; J. Am. Chem. Soc. 1990, 112, 5525.

55. Francisco, A. I.; Fragoso, T. P.; Vargas, M. D.; Carneiro, J. W. D.; Casellato, A.; Silva, F. C.; Ferreira, V. F.; Barbosa, J. P.; Pessoa, Costa-Lotufo, C. L. V.; Marinho Filho, J. D. B.; Moraes, M. O.; Mangrich, A. S.; J. Braz. Chem. Soc. 2010, 21, 1293

56. Fragoso, T. P.; Carneiro, J. W. D.; Vargas, M. D.; J. Mol. Model. $2010,16,825$.

57. Beak, P.; Covington, J. B.; Smith, S. G.; White, J. M.; Zeigler, J. M.; J. Org. Chem. 1980, 45, 1354.

58. Adamo, C.; Barone, V.; Loison, S.; Minichino, C.; J. Chem. Soc., Perkin Trans. 1993, 697.

Submitted: November 14, 2012 Published online: January 16, 2013 